\title{
News from the International Union for Pure and Applied Biophysics
}

\author{
First Announcement \\ SIXTH INTERNATIONAL BIOPHYSICS CONGRESS \\ 3-9 SEPTEMBER 1978 \\ Kyoto International Conference Hall, Japan
}

The Scientific Programme will include symposia of invited lectures and poster sessions for contributed papers.

SymPOSIA

The tentative titles of symposia are

I. Primary processes in muscle contraction

2. Contractile proteins in muscle and other tissues

3. Movement in sperm, cilia and bacterial flagella

4. Molecular motion and structure of membranes

5. Membrane assembly

6. The molecular basis of excitability

7. Photophysical processes

8. Bioenergetics

9. Biophysics of hemoproteins

10. Folding of proteins and nucleic acids

I1. Specific interaction of tRNA and amino acyl-tRNA synthetase

12. Structure of chromatin

13. Structure and function of multi-macromolecular systems

I4. Quantum biophysics

15. Physical methods

I6. Environmental biophysics

17. Animal communication in and with the environment

18. Analysis of visual information by the nervous system

19. Mathematical models in biophysics

20. Biorheology: cellular deformation, passive and active

21. 3-Dimensional studies of body structure

22. Biophysical problems in a high saline environment

23. Applications of gel-entrapped organelles and cells in enzyme engineering

\section{Poster Sessions}

Registered members of the Congress can contribute papers to be presented at Poster Sessions. All fields of Biophysics will be covered. 


\section{Participation}

Information regarding the registration fee will be announced in the Second Circular, which will be available in August 1977.

A limited number of fellowships will be available for young scientists to cover living expenses in Kyoto during the Congress.

\section{CORRESPONDENCE}

All correspondence concerning the Congress should be sent to:

Professor F um Io Oosa Wa (Secretary General)

Sixth International Biophysics Congress

Department of Biophysical Engineering

Osaka University, Toyonaka, Osaka 560, Japan

Requests for preliminary registration forms should reach the Secretary General before 3 I March 1977.

\section{Forthcoming Meetings}

May

9-12 European Seminar on Biological Solar Energy Conversion Systems. Grenoble-Autrans, France. Write: Secretariat: Dr P. M. Vignais, DRF/Biochimie, C.E.N.-G., 85X, 3804I Grenoble-Cedex, France.

fuly

4-8 2nd International Advanced Course of Bioenergetics on 'Specialized Membrane Functions', Rome, Italy. Write: Dr S. Papa, Istituto di Chimica Biologica, Via Amendola I65/A, 70126, Bari, Italy.

IO-I 5 International Symposium on Membrane Bioenergetics, Island of Spetsai, Greece. Write: Dr G. C. Papageorgiou, NRC Democritos, Department of Biology, Aghia Paraskevi, Athens, Greece.

18-23 XXVII International Congress of Physiological Sciences, Paris, France. Write: Professor J. Scherrer, Departement de Physiologie,

U.E.R. Pitie Salpetriere, Cedex I300, F-75300, Paris-Brune, France.

August

25-27 Linderström-Lang Conference on 'Biochemical Control Mechanisms of Respiration at the Molecular and Tissue Level', Hanaholmen, near Helsinki, Finland. Write: Dr N. E. Saris, Department of Medical Chemistry, University of Helsinki, Siltavuorenpenger 10, 001 70 Helsinki I7, Finland.

\section{September}

4-10 26th IUPAC Congress, Tokyo, Japan.

\section{Autumn}

VIth International Symposium on Magnetic Resonance, Banff, Alberta.

Write: Dr L. W. Reeves, Department of Chemistry, University of Waterloo, Waterloo, Ontario, Canada $\mathrm{N}_{2} \mathrm{~L}_{3} \mathrm{GI}$.

October

I I-I 2 First Congress of the Federation of Asian and Oceanian Biochemists, Nagoya, Japan. Write: Dr Tasashi Mucarhi, Department of Clinical

Science, Kyoto University Hospital, Faculty of Medicine, Sakyoku, Kyoto 606, Japan.

\section{November}

9-I I International Conference on Atherosclerosis(Milan). Write: Fondazione

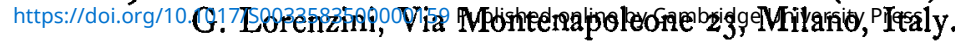

